\title{
Производство арбуза на юге России: проблемы и перспективы
}

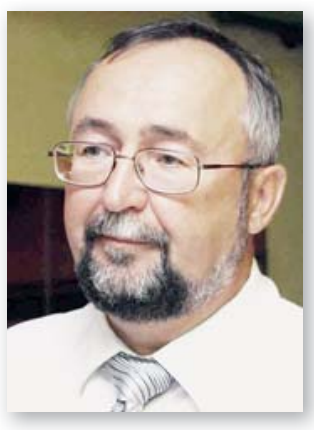

Ю.А. Быковский

В статье приведен анализ состояния товарного бахчеводства в Российской Федерации, рассмотрен ряд проблем, влияющих на развитие отрасли: нехватка окультуренных для бахчеводства земель, отсутствие севооборотов и т.д. Приводится краткий обзор сортимента основной культуры - столового арбуза, представленного на рынке зарубежными и отечественными семенными компаниями.

Ключевые слова: бахчеводство, арбуз, сорта, гибриды, сортотип, сортимент.

ахчеводство традиционно было
гордостью российского сель-
ского хозяйства. Зарубежные ученые и путешественники еще в XVIII веке восторгались громадными размерами и отменным вкусом арбузов Камышина, Быково, Царицына и Астрахани. В 1925 году в СССР бахчевые занимали площадь 1 млн 145 тыс. га, в том числе в РСФСР - 560 тыс. га, а валовой сбор их составлял более 4 млн т, причем 70\% урожая, был представлен арбузами, 20\% - дынями, $10 \%$ - тыквой [1]. Сегодня в России бахчевые культуры занимают 140-160 тыс. га, а их валовое производство составляет около 1 млн т.

Особенность бахчевых культур формировать довольно высокий урожай в условиях полупустыни обеспечила популярность этой культуры в тех регионах, где возделывание других культур крайне рискованно. По данным компании Global Reach Consulting (GRC), бахчевые культуры находятся в верхней строчке мирового рейтинга овощных культур по урожайности, уступая лишь грибам и томатам [2].

В период становления товарного бахчеводства лучшими по качеству считались арбузы, выращенные в богарных условиях Быковского района Сталинградской области, которые накапливали до 7,2-8,9\% сахаров, преимущественно фруктозы (сорта Быковский, Мурашка, Черноусик, Мраморный) [3].

Несмотря на непростую ситуацию в сельском хозяйстве России, отрасль бахчеводства в зоне рискованного земледелия остается одной из прибыльных [4].
В зависимости от погодных условий, в последние годы, 20-30\% от общего количества валового производства бахчевых остается невостребованным потребителями. Как следствие перепроизводства оптовые цены на бахчевую продукцию снижаются, уменьшая рентабельность бахчеводства. К сожалению, современное товарное бахчеводство несет с собой ряд проблем, которые обострятся в ближайшем будущем. Нехватка земель, пригодных для возделывания бахчевых культур, приводит к практике монокультуры, что в свою очередь ведет к накоплению патогенных микроорганизмов и вредителей, а при наличии благоприятных погодных условий может привести к массовым вспышкам заболеваний бахчевых и значительным потерям урожая от болезней и вредителей (луговой мотылек, дынная муха, саранча, фузариоз). Отсутствие в крестьянских хозяйствах средств и земель для севооборотов приводит к освоению одного из экстенсивных типов бахчеводства - кочующему бахчеводству, со всеми вытекающими последствиями (резкое сокращение земель, пригодных для бахчеводства; засорение полей сорной растительностью и выведение их из хозяйственного оборота и т.д.). В таких условиях большую роль приобретают мероприятия, направленные на профилактическое предупреждение развития болезней и вредителей (своевременные междурядные обработки и прополки в рядках, опрыскивание пестицидами с добавлением хлористого калия, регуляторов роста и т.д.)
Сегодня многие фермерские хозяйства перешли на самообеспечение семенным материалом, который в силу невозможности соблюдения пространственной изоляции, является гибридом от смеси сортов, возделываемых в этом хозяйстве, что приводит к потере сортовых качеств бахчевых и снижению урожайности. Стремление к получению максимального урожая, особенно при применении временных пленочных укрытий, в большинстве случаев приводит к неконтролируемому применению азотных удобрений, делая продукцию не только малосъедобной, но и токсичной для человека.

Вместе с тем, следует отметить и ряд положительных тенденций, вызванных введением рыночной экономики в стране. Стала заметна специализация хозяйств на производстве бахчевых различных сроков созревания: ряд хозяйств специализируется на производстве ранней продукции бахчеводства с использованием временных пленочных укрытий, стали востребованы ранние и ультраранние сорта; отдельные хозяйства наоборот специализируются на производстве позднеспелых сортов арбуза, пригодных к длительному хранению, используя для хранения различные виды хранилищ. Таким образом, значительно расширяется период потребления продукции бахчеводства в стране.

В последнее время проявляется интерес к вопросам переработки продукции бахчеводства: производство технических семян бахчевых культур с последующей их переработкой в различные виды продукции (масло, лекарственные препараты, красители и т.д.); переработка арбузов с целью получения других видов продукции - цукатов, концентрата арбузного сока (нардек) и т.д.

Вместе с тем помимо совершенствования приемов возделывания (применение стимуляторов роста, различных способов предпосевной подготовки семян, применение новых форм удобрений, укрытий, орошения и т.д.) отмечается существенное расши- 


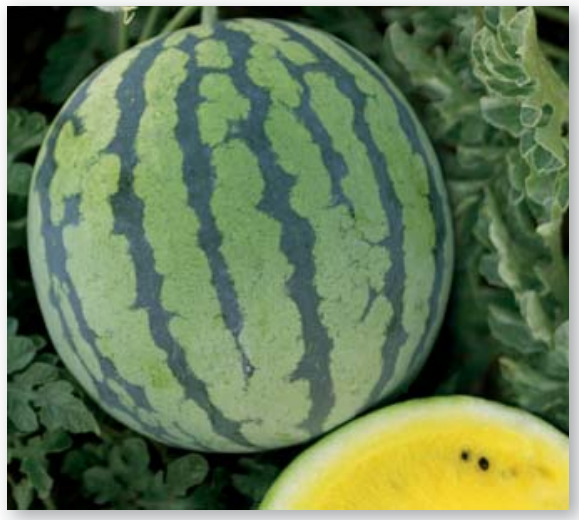

Рис. 1. Сорт арбуза Золотой реванш

рение сортимента столового арбуза предлагаемого к возделыванию в зоне товарного бахчеводства.

Анализируя наличие сортов и гибридов в Государственном реестре селекционных достижений, допущенных к использованию на 2019 год [5], следует отметить, что за последние 10 лет количество сортов и гибридов арбуза увеличилось в три раза, 246 в 2019 году против 61 в 2008. Это практически на уровне Реестра США (271 сорт и гибрид арбуза), поэтому можно представить себе насколько большое разнообразие арбуза может быть предложено нашему потребителю. Стабильно увеличивается доля гибридов арбуза, в общем количестве представленных в Реестре сортов и гибридов, с 36\% в 2008 году до $62 \%$ в 2019. Подавляющее большинство гибридов арбуза в отечественном Реестре селекционных достижений на 2019 год представлено зарубежными компаниями, но цены на них порой в десятки раз отличаются от отечественных. Существует высокая потенциальная возможность вытеснения отечественных сортов и гибридов с отечественного рынка семян.

Из всех сортов и гибридов арбуза, представленных в Государственном реестре селекционных достижений, допущенных к использованию в 2019 году, более 50\% отно-

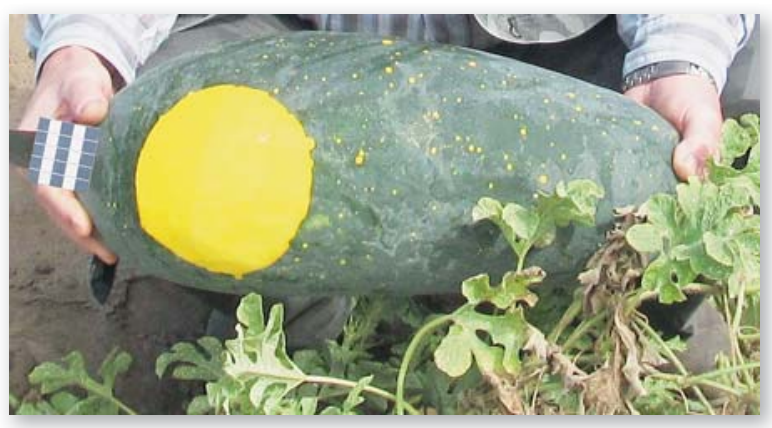

Рис. 3. Сорт арбуза Звезда

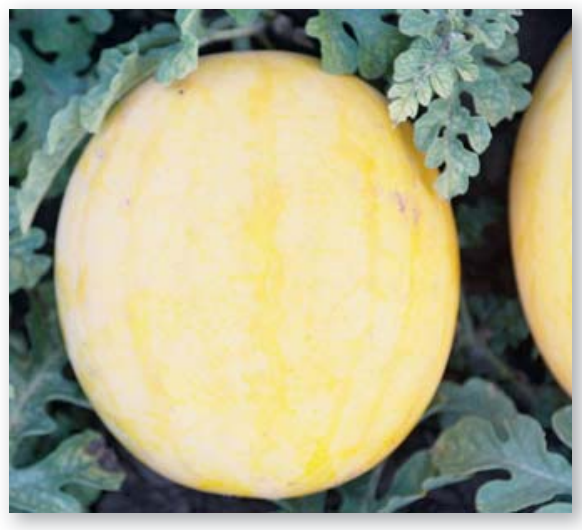

Рис. 2. Сорт арбуза Янтарный

сится к сортотипу Кримсон Свит. Популярный сорт арбуза, ставший лидером в товарном бахчеводстве, к сожалению, в последнее время утрачивает свои качества, первоначально заложенные его авторами десятилетия назад. Поэтому ряд зарубежных и отечественных компаний провели работу по улучшению отдельных сортовых характеристик сорта Кримсон Свит. Интерес представляют ряд сортов и гибридов арбуза, созданных российской компанией Агрохолдингом «Поиск» - совместно с зарубежными компаниями, такие, как: Кримсон Рекорд, Кримсон Вондер, гибриды $F_{1}$ Кримсон Спринт и $F_{1}$ Кримсон Премиум. Улучшающая работа, проведенная с широко известным сортом, позволила адаптировать новые сорта и гибриды к изменившимся погодным условиям (повысить устойчивость к местным расам антракноза и пониженным температурам в весенний период, сократить сроки созревания, повысить транспортабельность). Сорт арбуза Волгоградец обладает повышенной устойчивостью к солнечным ожогам, основному бичу товарного бахчеводства на юге России, и заслужил признание среди многих бахчеводов. В общей массе арбузов сортотипа Кримсон Свит, предлагаемых потребителям, неплохим коммерческим ходом может стать увеличение разнообразия сортотипов, особенно на местных рынках. Получили распространение сорта Быковской бахчевой селекционной опытной станции Холодок, Быковский 22, Икар, Волжанин и т.д. Агрохолдинг «Поиск» предлагает нашим потребителям сорта арбуза
Золотой реванш (рис. 1), Янтарный (рис. 2), Звезда (рис. 3), существенно отличающихся от общей массы сортов своим внешним видом и вкусом. Помимо арбуза, Агрохолдинг «Поиск», предлагает ряд сортов дыни, обладающих высокими потребительскими качествами способных удовлетворить самые высокие требования наших бахчеводов (сорта Млада, Фантазия, Дина, Эфиопка, Царская, Медовый спас, Золотой шар, Фортуна).

В современной селекции овощных культур большое значение придается их пищевым качествам, и арбуз может стать одним из лидеров среди этой группы культур. У плодов арбуза, как и у плодов других бахчевых растений, есть большой потенциал, как основного источника пищи и воды в полупустынных и пустынных регионах планеты, он остается весьма существенным компонентом лечебного и диетического питания, что позволяет этой культуре внести существенный вклад в человеческое здоровье в XXI веке.

Библиографический список 1. Фурса Т.Б. Арбуз. «Культурная флора СССР». Т. XXI, М.: Колос. С.164-211.

2.Мировой и российский рынок свежих овощей, Global Reach Consulting. 2011. Вып. 3. С. 218.

3.Лутохин С.И. Выращивание бахчевых культур и переработка их в сахарные концентраты. М.: Огиз-сельхозгиз, 1942. С. $2-44$.

4.Быковский Ю.А., Колебошина Т.Г. Особенности агротехники бахчевых культур в зоне рискованного земледелия РФ. Труды Кубанского государственного аграрного университета». 2016. № 60. С.123-129.

5.Государственный реестр селекционных достижений допущенных к использованию. Т. 1. "Сорта растений» (официальное издание). М.: ФГБНУ «Росинформагротех», 2018. 504 с.

\section{Об авторе}

Быковский Юрий Анатольевич, доктор с. - х. наук, профессор, Агрохолдинг «Поиск».

E-mail:info@semenasad.ru интернет-сайт: www.semenasad.ru

Production of watermelon on South of

Russia: problems and prospects Yu.A. Bykovskii, DSc, professor, Poisk Agro Holding.E-mail: info@semenasad.ru.

URL: www. semenasad.ru

Summary. The article analyzes the state of commodity melon production in the Russian Federation, considers a number of problems affecting the development of the industry: deficiency of cultivated land, absence of crop rotations etc. A brief overview of the range of the main culture - watermelon - presented on the market by foreign and domestic seed companies.

Keywords: melon, watermelon, varieties, hybrids, variety type, assortment. 